\title{
Analysis of the system of pricing of railway capacity allocation in the Czech Republic
}

\author{
Jaromir Siroky ${ }^{1, *}$ and Hana Salakova ${ }^{1}$ \\ ${ }^{1}$ University of Pardubice, Faculty of Transport Engineering, Department of Transport Technology and Control, Studentská 95 , 53210 \\ Pardubice, Czech Republic
}

\begin{abstract}
The introducing of legal background for capacity allocation in Czech Republic. The analysis of price for capacity allocation in Czech Republic and in Europe. The proposal of the capacity allocation price which should lead the Railway undertaking's path request to the suitable product. Possible impact of the price of capacity allocation to Railway undertaking's decision about the railway transport.
\end{abstract}

\section{Introduction}

Railway capacity is allocated using two basic modes, i.e. within processing the annual timetable and its changes, and in an ad hoc request mode. As for timetable 2017, the following (4) products are offered to applicants for railway capacity:

1. Regular request for railway capacity allocation to be taken into account when creating the annual timetable - "RJ",

2. Late request for railway capacity allocation to be taken into account when creating the annual timetable - "PJ",

3. Request for railway capacity allocation until the next change of the annual timetable - "ZJ",

4. Individual ad hoc request for railway capacity allocation.

As for individual ad hoc requests for railway capacity allocation, the applicants can use the following products:

a) Ad hoc request for railway capacity allocation submitted 3 and more working days before the first requested date of train departure (including the request date) - "N3",

b) Ad hoc request for railway capacity allocation submitted later than 3 working days before the first requested date of train departure (including the request date) - "P3" (residual railway capacity),

c) Ad hoc request for railway capacity allocation for technical and safety tests - "TB",

d) Ad hoc request for railway capacity allocation for test rides of vehicles of unapproved type or rides at a speed exceeding the track speed - "ZK",

e) Ad hoc request for railway capacity allocation for Railway Infrastructure Administration infrastructure maintenance - "UI",

f) Ad hoc request for railway capacity allocation due to Railway Infrastructure Administration infrastructure restrictions - "OM", g) Ad hoc request for railway capacity allocation for other reasons attributable to the Railway Infrastructure Administration - "JD".

\section{Railway Infrastructure Administration products related to capacity allocation}

Train route and train timetable are determined in assessing the request for railway capacity allocation. For requests for products $\mathrm{RJ}, \mathrm{PJ}, \mathrm{ZJ}, \mathrm{N} 3$, TB and $\mathrm{ZK}$, the timetable is created with conflict resolution.

As for requests for products $\mathrm{P} 3, \mathrm{UI}, \mathrm{OM}$ and JD, it is up to the allocator to decide whether to allocate ad hoc routes with conflict resolution, or routes within the residual railway capacity without resolving the conflicts. For routes within the residual railway capacity, conflicts are later resolved by operational employees of the infrastructure manager. Table 1 clearly shows that railway undertakings are increasingly using ad hoc requests compared to requests to be taken into account when creating the annual timetable.

This has been a trend for railway undertakings EUwide due to the increasing demand for greater flexibility, mainly in freight transport. The authors thus tried to summarise the advantages and disadvantages of both railway capacity allocation modes for railway undertakings.

Table 1. Evolution of the number of data timetables for the train traffic diagram 2005-2016.

\begin{tabular}{|c|c|c|}
\hline Year & $\begin{array}{c}\text { Number of routes } \\
\text { requested for the } \\
\text { annual timetable }\end{array}$ & $\begin{array}{c}\text { Number of ad hoc } \\
\text { allocation requests }\end{array}$ \\
\hline 2005 & 15.468 & 62.970 \\
\hline 2006 & 14.836 & 78.595 \\
\hline 2007 & 15.213 & 127.547 \\
\hline 2008 & 14.366 & 159.021 \\
\hline 2009 & 14.403 & 161.223 \\
\hline 2010 & 13.381 & 180.602 \\
\hline
\end{tabular}

Corresponding author: jaromir.siroky@upce.cz 


\begin{tabular}{|l|l|l|}
\hline 2011 & 13.107 & 185.100 \\
\hline 2012 & 12.706 & 181.647 \\
\hline 2013 & 12.023 & 205.993 \\
\hline 2014 & 11.704 & 240.460 \\
\hline 2015 & $13.361 \quad 252.797$ \\
\hline \multicolumn{2}{|c|}{ Source: Authors according to (16) } \\
\hline
\end{tabular}

Mode of allocation within the annual timetable products $\mathbf{R J}, \mathbf{P J}$ and $\mathrm{ZJ}$

Each of the railway capacity allocation modes has its advantages and disadvantages.

Advantages of requests for railway capacity allocation to be taken into account when creating the annual timetable:

- higher quality of timetable processing,

- priority processing,

- determination of technologies at originating, intermediary, destination and frontier stations,

- with a higher number of route-days, the price of railway capacity per route-day is lower.

Disadvantages of requests for railway capacity allocation to be taken into account when creating the annual timetable:

- greater risk of sanctions for unused railway capacity due to a large time gap between the time of booking the route and the actual train ride,

- low flexibility of changes for railway undertakings,

- greater limitation by the booked route parameters (where the business case changes, the railway undertaking has to submit an individual ad hoc request for railway capacity allocation - e.g. upon extension of the original route).

Ad hoc allocation mode - products N3, P3, TB, ZK, UI, OM and JD

Individual ad hoc requests for railway capacity allocation have their advantages and disadvantages as well.

Advantages of individual ad hoc requests for railway capacity allocation:

- greater flexibility for railway undertakings,

- greater probability of using the route, and thus a lower risk of sanctions for unused railway capacity,

- lower price of railway capacity allocation with a lower number of route-days, more flexible adaptation to changing market requirements.

Disadvantages of individual ad hoc requests for railway capacity allocation:

- lower quality of timetable processing (mainly in residual railway capacity routes) without conflict resolution,

- lower priority in timetable processing,

- need for the railway undertaking to negotiate technologies at stations (originating, intermediary, destination and frontier) on a case-by-case basis,

- impossibility to use certain tender prices, e.g. tender price $\mathrm{J}$.
With the increasing number of requests for railway capacity allocation, mainly in the ad hoc mode, it is necessary to manage the railway undertakings to submit their requests for railway capacity allocation in time to ensure a timely and high quality processing of timetables, and to prevent them from submitting requests in the annual timetable allocation mode, which are ad hoc requests in nature. One of the ways to motivate the railway undertakings to use appropriate products is pricing the products in a way that the railway undertakings get the best value for money, and the price covers the costs reasonably incurred in railway capacity allocation at the same time.

Railway Infrastructure Administration products related to capacity allocation and their prices (for timetable 2017) are shown in Table 2. Coefficients K1, $\mathrm{K} 2$, and $\mathrm{K} 3$ are rates used in formula (1) to calculate the price of railway capacity allocation.

Table 2. Railway Infrastructure Administration products related to capacity allocation for timetable 2017.

\begin{tabular}{|l|c|c|c|c|}
\hline \multicolumn{2}{|c|}{ Product } & K1 & K2 & K3 \\
\hline RJ & $\begin{array}{c}\text { regular request for railway capacity } \\
\text { allocation to be taken into account } \\
\text { when creating the annual timetable }\end{array}$ & 1.700 & 8 & 10 \\
\hline PJ & $\begin{array}{c}\text { late request for railway capacity } \\
\text { allocation to be taken into account } \\
\text { when creating the annual timetable }\end{array}$ & 1.700 & 10 & 20 \\
\hline ZJ & $\begin{array}{c}\text { request for railway capacity } \\
\text { allocation until the regular change } \\
\text { of the annual timetable }\end{array}$ & 1.700 & 10 & 20 \\
\hline N3 & $\begin{array}{c}\text { ad hoc request for railway capacity } \\
\text { allocation submitted 3 and more } \\
\text { working days in advance }\end{array}$ & 100 & 0 & 70 \\
\hline TB & $\begin{array}{c}\text { ad hoc request for railway capacity } \\
\text { allocation submitted later than 3 } \\
\text { working days in advance }\end{array}$ & 100 & 0 & 160 \\
\hline ZK & $\begin{array}{c}\text { ad hoc request for railway capacity } \\
\text { allocation for technical and safety } \\
\text { tests of railway vehicles }\end{array}$ & 480 & 0 & 70 \\
$\begin{array}{c}\text { ad hoc request for railway capacity } \\
\text { allocation for test rides of vehicles } \\
\text { of unapproved type or rides at a } \\
\text { speed exceeding the track speed }\end{array}$ & 960 & 0 & 70 \\
\hline
\end{tabular}

Source: [4]

The payment for railway capacity allocation was introduced in 2004 (before 2004, railway capacity allocation was not subject to a charge) to regulate the behaviour of railway undertakings in railway transport planning.

The system was devised as a rate times the number of route-days (days the train spends on the route). Originally, 3 rates had been determined as follows: CZK 15 per route-day for allocation within the annual timetable, CZK 25 per route-day for requests submitted 3 and more working days before the first day of the train ride, and CZK 120 per route-day for requests submitted later than 3 working days before the first day of the train ride (residual railway capacity). These rates had applied until 2010.

With timetable 2013, rates $\mathrm{K} 1, \mathrm{~K} 2$ and $\mathrm{K} 3$ were introduced, and in addition to the rate per route and route-day, rates per kilometre of the planned route 
started to be charged as well. $\mathrm{K} 1$ is the price of processing and determining of the timetable and railway capacity allocation, $\mathrm{K} 2$ is the price of train route creation, and $\mathrm{K} 3$ is the price of train route allocation per day.

$\mathrm{K} 1$ amounting to $\mathrm{CZK}$ 1,700 applies to all products within the annual timetable (regular request, late request and request until the next change of the annual timetable - products RJ, PJ and ZJ), and K2 in the amount of CZK 100 applies to ad hoc requests for railway capacity submitted 3 and more working days in advance (product N3) and requests for railway capacity submitted later than 3 working days in advance (product P3). K1 for ad hoc requests for railway capacity allocation for technical and safety tests of railway vehicles remained at CZK 480 (product TB), and for ad hoc requests for railway capacity allocation for test rides of vehicles of unapproved type or rides at a speed exceeding the track speed remained the same as well (CZK 960) (product $\mathrm{ZK})$.

$\mathrm{K} 2$ for RJ was fixed at CZK 8 per 1 route kilometre, and for products $\mathrm{PJ}$ and $\mathrm{ZJ}$ at $\mathrm{CZK} 10$ per 1 route kilometre. For the other products N3, P3, TB and ZK, $\mathrm{K} 2$ was fixed at CZK 0 per 1 route kilometre.

$\mathrm{K} 3$ for $\mathrm{RJ}$ is CZK 10 per day of train route allocation, for $\mathrm{PJ}$ and $\mathrm{ZJ}$ it's CZK 20 per day of train route allocation, for N3 it's CZK 70 per day of train route allocation. For P3, K3 was fixed at CZK 160 per day of train route allocation and for $\mathrm{TB}$ and $\mathrm{ZK}, \mathrm{K} 3$ amounts to CZK 70 per day of train route allocation.

Revenue from railway capacity allocation should cover the total direct costs of railway capacity allocation, but cannot exceed them. Using MS Excel, prices of railway capacity allocation will be modelled that would take into account all economically justifiable costs of railway capacity allocation, and would motivate railway undertakings to book the individual products in an optimal way at the same time.

\section{Requests for railway capacity allocation}

To properly regulate the demand of railway undertakings for individual products, it is first necessary to define the requirements on target groups of these respective products.

\subsection{Requests for railway capacity allocation to be taken into account when creating the annual timetable and its changes - products RJ, PJ and ZJ}

These products are meant for requests for highfrequency train rides (ideally with daily frequency) requiring the creation of a fixed train route to be strictly adhered to and containing other requirements:

- creation of transfer connections,

- creation of passenger service train cycles,

- creation of offered departure or arrival times,

- determination of technologies at originating, intermediary, destination and frontier stations.
The requests are submitted at the times agreed on European level, and timetables proposed by capacity allocator are submitted at the times defined by national legislation and European agreements as well.

a) Regular request for railway capacity allocation to be taken into account when creating the annual timetable - product $\mathbf{R J}$

For RJ, requests are processed with highest quality (in a "blank" train traffic diagram sheet). Subsequently, detailed information is provided on the timetable implementation in a train diagram, working timetable and booking timetable. A RJ request should be more cost effective than $\mathrm{PJ}$ or $\mathrm{ZJ}$ ones for the applicants to be motivated to submit requests earlier, which is advantageous for creating a timetable as there is more time for the route creation. With a higher number of route-days, the price of railway capacity per route-day should be lower. The proposed price of RJ, PJ and ZJ should also be lower for railway undertakings than the price of N3 for a number of route-days greater than the limit number.

b) Late request for railway capacity allocation to be taken into account when creating the annual timetable - product PJ

$\mathrm{PJ}$ is meant for requests submitted after the regular request deadline. For these requests, it is not always possible to guarantee the requested time frame, the route is created within an already created timetable, and the necessary effort is similar, or slightly higher than for regular requests.

The proposed price should be higher than for RJ requests.

c) Request for railway capacity allocation until the next change of the annual timetable - product $\mathrm{ZJ}$

$\mathrm{ZJ}$ is meant for requests which compared to ad hoc requests require higher quality and the processing of the necessary instruments is more demanding. The route creation (within an already created timetable) is similar and requires similar effort as in late requests. The proposed price should be higher or the same as in late requests.

\subsection{Individual ad hoc requests for railway capacity allocation - products N3, P3, TB, ZK, UI, OM and JD}

This category includes individual and less frequent requests within the period between timetable changes, and sometimes also longer-term requests with a departure date within the period between timetable changes (with limited requirements on links to other requests or on defining arrival and departure time frames for selected stations).

a) Individual ad hoc request for railway capacity allocation submitted 3 and more working days in advance - product $\mathbf{N} 3$

For this request, a timetable is created within a period between timetable changes, which is then included in the next timetable change. These are often requests in response to planned closures, and the route creation 
requires similar effort as in requests until the next change of the annual timetable. What is different is the lower quality of timetable information, requiring railway undertakings to use more information sources.

In some cases, there is a need for more consultations with railway undertakings, technologists, etc., and the processing effort is thus higher. For a number of routedays greater than the limit number, the proposed price of N3 should be higher than for ZJ, but at the same time lower than for P3.

b) Individual ad hoc request for railway capacity allocation submitted later than 3 working days in advance - product $P 3$

P3 includes one-time, casual or irregular transport requests (the applicant doesn't know the exact ride date in advance) submitted very shortly before the actual ride. There is less time for request processing and time frame allocation (in extreme cases only in the order of minutes), and conflicts between the new route and existing ones are not resolved at the route creation stage (they are only resolved operationally later). The requested and actually allocated route parameters differ more than in above mentioned requests, timetable quality is lower, the most important criteria being the speed of processing whilst respecting a certain level of route safety (sticking to absolute route parameters), and giving all necessary information on the route to all operational employees. Technologies at originating, intermediary, destination and frontier stations are negotiated by the railway undertaking on a case-by-case basis. The proposed price should be higher than for N3 requests.

c) Individual ad hoc request for railway capacity allocation for technical and safety tests of railway vehicles, for test rides of vehicles of unapproved type or rides at a speed exceeding the track speed - products $T B$ and $Z K$

Categories $\mathrm{TB}$ and $\mathrm{ZK}$ include requests for railway capacity allocation for technical and safety tests of railway vehicles, for test rides of vehicles of unapproved type or rides at a speed exceeding the track speed, submitted by railway undertakings in the individual ad hoc mode as these types of train rides are not made regularly, but only as needed, and the exact date of these rides cannot be predicted long time in advance.

The proposed price of railway capacity allocation (for $\mathrm{TB}$ and $\mathrm{ZK}$ ) must reflect the highly demanding nature of request processing, as finding a suitable route and creating a timetable with the necessary measures is time consuming due to a greater need to consult several aspects of route allocation, and the costs of the necessary instruments are higher due to several technical and organisational measures required for the train ride. The request must be submitted for processing more than 3 working days before the intended departure date. The proposed price is based on the price of N3, taking into account route creation specifications.

d) Individual ad hoc request for railway capacity allocation for maintenance, restoration and increasing of usable capacity - products UI, OM and JD

For train rides made in connection with diagnostics and maintenance of infrastructure of the Railway Infrastructure Administration (UI, OM and JD), i.e. for the needs of the Railway Infrastructure Administration, $100 \%$ discount is provided on railway capacity allocation. For train rides made due to infrastructure restrictions attributable to the Railway Infrastructure Administration (i.e. planned and unexpected closures and irregularities), capacity is provided for free, these being rides capacity has already been allocated for (train redirections), or railway undertakings' rides due to infrastructure restrictions which otherwise wouldn't be necessary (bringing and carrying away necessary items).

The aim of the regulatory function of the price of railway capacity is to regulate requests so that long-term requests are submitted in the mode of the annual timetable and its changes, and short-term requests in the ad hoc mode. At the same time, it is necessary to take into account the effort and processing quality, and the following:

a) Quality of route creation and the effort required,

- dependence on route length and the necessary negotiations with other entities,

- passenger trains - negotiation with state administration - with ordering railway undertakings,

- adopting other measures related to the route use,

- dependence on the length of the period of route use, as the probability of finding a suitable route decreases and its creation becomes more complicated, and the probability of free slots being occupied by requests submitted earlier increases,

b) Quality of the necessary instruments and the effort required,

- creation of a train diagram and working timetable,

- creation of a booking timetable for passengers,

- creation of a data timetable and its distribution to subsequent information systems,

c) Time period of train route use - route booking.

The maximum number of route-days for regular and late requests and requests until the next change of the annual timetable established by the authors is based on the deadlines for the creation of the annual timetable and its planned changes, the maximum number of route-days for individual ad hoc requests submitted 3 and more working days in advance is based on the defined requirements on target groups of requests for individual and less frequent requests within the period between timetable changes, and sometimes also longer-term requests with a departure date within the period between timetable changes. The maximum number of route-days for individual ad hoc requests submitted later than 3 working days in advance starts from the assumption of the most inconvenient accumulation of Christmas bank holidays ( 3 working days, 3 bank holidays on working days and twice 2 weekend days). 
Table 3. Allocated data timetables in 2016 by products in the annual timetable

\begin{tabular}{|c|c|c|c|c|}
\hline \multicolumn{5}{|c|}{ Allocated data timetables in 2016 - by products in the annual timetable } \\
\hline & RJ & PJ & ZJ & Total \\
\hline Number of data timetables & 13.686 & 788 & 485 & 14.959 \\
\hline Number of route-days & 2.899 .051 & 132.265 & 32.170 & 3.063 .486 \\
\hline Total length $[\mathrm{km}]$ & 731.593 & 37.661 & 33.727 & 802.981 \\
\hline Total price $[\mathrm{CZK}]$ & 58.109 .454 & 4.361 .513 & 1.805 .166 & 64.276 .133 \\
\hline Average number of route-days per data timetable & 211.8 & 167.8 & 66.3 & 204.8 \\
\hline Average length $[\mathrm{km}$ per data timetable $]$ & 53.5 & 47.8 & 69.5 & 53.7 \\
\hline Average price [CZK per data timetable] & 4.245 .9 & 5.534 .9 & 3.722 .0 & 4.296 .8 \\
\hline
\end{tabular}

The difference between the allocated data timetables and allocated route-days, as shown in Table 3, consists in the fact that one data timetable can be allocated for more route-days. The Table shows the calculated average number of allocated route-days, route length and price of railway capacity allocation by products in the year concerned in the annual timetable mode.
Table 4 shows the difference between allocated data timetables and allocated route-days in the ad hoc mode. The Table also shows the calculated average number of allocated route-days, route length and price of railway capacity allocation by products in the year concerned in the ad hoc mode.

Table 4. Allocated data timetables in 2016 by ad hoc products

\begin{tabular}{|l|l|l|l|l|l|}
\hline Allocated data timetables in 2016-by products in the annual timetable & \multicolumn{4}{l|}{ - } \\
\hline & N3 & P3 & TB & ZK & Total \\
\hline Number of data timetables & 13.534 & 159.968 & 196 & 285 & 173.983 \\
\hline Number of route-days & 26.400 & 160.943 & 196 & 367 & 187.906 \\
\hline Total length [km] & 1.357 .650 & 11.491 .204 & 9.742 & 11.492 & 12.870 .088 \\
\hline Total price [CZK] & 3.201 .400 & 41.747 .680 & 107.800 & 299.290 & 45.356 .170 \\
\hline Average number of route-days per data timetable & 2.0 & 1.0 & 1.0 & 1.3 & 1.1 \\
\hline Average length [km per data timetable] & 100.3 & 71.8 & 49.7 & 40.3 & 74.0 \\
\hline Average price [CZK per data timetable] & 236.5 & 261.0 & 550.0 & 1.050 .1 & 260.7 \\
\hline
\end{tabular}

Source: Authors according to (24)

Table 4 does not contain products UI, OM and JD (ad hoc products); even though these represent a considerable number of allocated data timetables, routedays and kilometres of route length, they do not factor in the price of railway capacity allocation as their price hasn't been set.

The price of railway capacity allocation is calculated using formula (1):

$$
C K=K 1+K 2 \cdot D t r+K 3 \cdot P d j[\mathrm{CZK}]
$$

where:

- $C K$ is the total price of railway capacity allocation [CZK],

- $K 1$ is the price of processing and determining of the timetable and railway capacity allocation [CZK],

- $K 2$ is the price of train route creation [CZK per km],

- $K 3$ is the price of train route allocation per day [CZK per day],

- Dtr is the route length; the distance between point of origin and point of destination on railway network, where the Railway Infrastructure Administration functions as infrastructure manager, or capacity allocator $[\mathrm{km}]$,

- $\quad P d j$ is the number of route-days the route is allocated for [day].

Based on formula (1), the authors calculated limit values for the number of allocated route-days of the individual products subject to charge in the annual timetable, i.e. RJ, PJ, and ZJ. For requests matching the product definition, a condition was set stipulating that products in the annual timetable mode must be more cost effective than ad hoc products for a number of days greater than the limit number. A one-time ride in the annual timetable mode will always be more expensive than in the ad hoc mode. As a result, the following limiting conditions: $\mathrm{RJ}<\mathrm{N} 3, \mathrm{PJ}<\mathrm{N} 3, \mathrm{ZJ}<\mathrm{N} 3$ and motivational conditions: $\mathrm{RJ}<\mathrm{PJ}$ and $\mathrm{N} 3<\mathrm{P} 3$ can be formulated. Limiting conditions apply to a number of days greater than the limit number and motivational conditions apply to an arbitrary number of route-days. The current limit values were calculated using average values (Table 5) of individual products from the 2016 dataset.

Table 5. Allocated data timetables in 2016 by ad hoc products

\begin{tabular}{|c|c|c|c|c|c|}
\hline \multicolumn{6}{|c|}{$\begin{array}{l}\text { Allocated data timetables in } 2016 \text { - by products in the } \\
\text { annual timetable }\end{array}$} \\
\hline & RJ & PJ & $\mathbf{Z J}$ & N3 & P3 \\
\hline $\begin{array}{l}\text { Average number of } \\
\text { route-days per data } \\
\text { timetable }\end{array}$ & 211.8 & 167.8 & 66.3 & 2.0 & 1.0 \\
\hline $\begin{array}{lr}\text { Average route } \\
\text { length }[\mathrm{km} \text { per data } \\
\text { timetable] }\end{array}$ & 53.5 & 47.8 & 69.5 & 100.3 & 71.8 \\
\hline
\end{tabular}

The authors modified formula (1) to fit inequations to calculate limit values for allocated route-days for products RJ, PJ and ZJ (annual timetable) compared to product N3 (ad hoc).

The limit values were calculated to establish the break-even point in the number of route-days, based on 
which requests should be moved from the ad hoc mode to the respective products in the annual timetable mode. The author marked the calculated break-even point in the number of route-days as the unknown x. For the system to work, the price of railway capacity allocation for $\mathrm{RJ}$, $\mathrm{PJ}$ or $\mathrm{ZJ}$ for $\mathrm{X}-1$ and fewer route-days should be higher than the price of railway capacity allocation for $\mathrm{N} 3$ for $\mathrm{X}$ 1 and fewer route-days. For limit number of route-days, the following inequalities (2), (3), (4), and (5) apply.

$$
(R J, P J, Z J) \leq C(N 3)
$$

$$
\begin{gathered}
K 1+K 2 \cdot \operatorname{DtrRJ}+K 3 \cdot P d j R J x N 3 \leq K 1+K 2 \cdot \\
D t r R J+K 3 \cdot P d j R J x N 3 \\
K 1+K 2 \cdot D \operatorname{DtPJ}+K 3 \cdot P d j P J x N 3 \leq K 1+K 2 \cdot \\
D t r P J+K 3 \cdot P d j P J x N 3 \\
K 1+K 2 \cdot \operatorname{DtrZJ}+K 3 \cdot P d j Z J x N 3 \leq K 1+K 2 . \\
D t r Z J+K 3 \cdot P d j Z J x N 3
\end{gathered}
$$

where:

$(R J)$ is the price of railway capacity allocation for RJ [CZK],

$(\mathrm{PJ})$ is the price of railway capacity allocation for $\mathrm{PJ}$ [CZK],

$(\mathrm{ZJ})$ is the price of railway capacity allocation for $\mathrm{ZJ}$ $[\mathrm{CZK}]$,

(N3) is the price of railway capacity allocation for $\mathrm{N} 3$ $[\mathrm{CZK}]$,

$K 1$ is the price of processing and determining of the timetable and railway capacity allocation $[\mathrm{CZK}]$,

$K 2$ is the price of train route creation [CZK per km],

$K 3$ is the price of route allocation per day [CZK per day],

$D \operatorname{tr} R J$ is the length of the average RJ route; the distance between point of origin and point of destination on railway network, where the Railway Infrastructure Administration functions as infrastructure manager, or capacity allocator $[\mathrm{km}]$,

$D \operatorname{tr} P J$ is the length of the average PJ route; the distance between point of origin and point of destination on railway network, where the Railway Infrastructure Administration functions as infrastructure manager, or capacity allocator $[\mathrm{km}]$,

$D \operatorname{tr} Z J$ is the length of the average PJ route; the distance between point of origin and point of destination on railway network, where the Railway Infrastructure Administration functions as infrastructure manager, or capacity allocator $[\mathrm{km}]$,

$P d j R J x N 3$ limit number of route-days for RJ compared with N3 the respective route is allocated for [day],

$P d j P J x N 3$ limit number of route-days for PJ compared with N3 the respective route is allocated for [day], PdjZJxN3 limit number of route-days for ZJ compared with $\mathrm{N} 3$ the respective route is allocated for [day].

The calculation was made according to formulas (3), (4) and (5), where the number of route-days $P d j$ was used as the unknown $\mathrm{x}$.

After substitution, the inequation for RJ is as follows:

$K 1 R J+K 2 R J \cdot D t r R J+K 3 R J \cdot P d j R J x N 3 \leq$

$K 1 N 3+K 2 N 3 \cdot D \operatorname{trRJ} x N 3+K 3 N 3 \cdot P \operatorname{djRJ} x N 3)$

$$
\begin{gathered}
1700+8 \cdot 53.5+10 \cdot x \leq 100+0 \cdot 53.5+70 \cdot x \\
33.8 \leq x
\end{gathered}
$$

The limit value $\mathrm{x}$ for the number of route-days for $\mathrm{RJ}$ was rounded to 34 . The same substitution was performed for products PJ and ZJ. The results are interpreted in Table 12.

After substitution, the inequation for RJ is as follows:

$K 1 P J+K 2 P J \cdot D t r P J+K 3 P J \cdot P d j P J x N 3 \leq$ $K 1 N 3+K 2 N 3 \cdot D \operatorname{tr} P J x N 3+K 3 N 3 \cdot P \operatorname{djPJxN} 3$

$$
\begin{aligned}
1700+10 \cdot 47.8+20 \cdot x & \leq 100+0 \cdot 47.8+70 \cdot x \\
41.6 & \leq x
\end{aligned}
$$

The limit value $\mathrm{x}$ for the number of route-days for PJ was rounded to 42 .

After substitution, the inequation for $\mathrm{ZJ}$ is as follows:

$$
\begin{aligned}
& K 1 Z J+K 2 Z J \cdot D t r Z J+K 3 Z J \cdot P d j Z J \leq K 1 N 3 \\
& \quad+K 2 N 3 \cdot D \operatorname{tr} Z J x N 3+K 3 N 3 \cdot P d j Z J x N 3
\end{aligned}
$$

$$
\begin{gathered}
1700+10 \cdot 69.5+20 \cdot x \leq 100+0 \cdot 69.5+70 \cdot x \\
45.9 \leq x
\end{gathered}
$$

The limit value $\mathrm{x}$ for the number of route-days for $\mathrm{ZJ}$ was rounded to 46 . The calculated limit values are summarised in Table 6.

Table 6. Calculated limit values for allocated route-days and comparison of prices for selected products

\begin{tabular}{|l|l|l|l|}
\hline \multicolumn{1}{|c|}{ Product } & RJ & PJ & ZJ \\
\hline Number of route-days $\boldsymbol{x}$-1 & $\mathbf{3 3}$ & $\mathbf{4 1}$ & $\mathbf{4 5}$ \\
\hline Price of product RJ, PJ, ZJ [CZK] & 2.458 & 2.998 & 3.295 \\
\hline Price of product N3 [CZK] & 2.410 & 2.970 & 3.250 \\
\hline Limit number of route-days $\boldsymbol{x}$ & $\mathbf{3 4}$ & $\mathbf{4 2}$ & $\mathbf{4 6}$ \\
\hline Price of product RJ, PJ, ZJ [CZK] & 2.468 & 3.018 & 3.315 \\
\hline Price of product N3 [CZK] & 2.480 & 3.040 & 3.320 \\
\hline
\end{tabular}

The Table shows that with 34 and more allocated route-days for RJ, the price of allocated railway capacity is lower than the price of railway capacity allocation for $\mathrm{N} 3$ with the current coefficients K1, K2 and K3. With 42 and more allocated route-days for $\mathrm{PJ}$, the price of allocated railway capacity is lower than the price of railway capacity allocation for $\mathrm{N} 3$.

With 46 and more allocated route-days for $\mathrm{ZJ}$, the price of allocated railway capacity (for the average route length of RJ, PJ and $\mathrm{ZJ}$ ) is lower than the price of railway capacity allocation for $\mathrm{N} 3$.

The aim of the proposed change to the price of railway capacity allocation was for the price to have a regulatory function and at the same time, to cover the direct costs incurred by the Railway Infrastructure Administration in connection with railway capacity allocation, with the revenue from the railway capacity allocation not exceeding these direct costs. Economic assessment was conducted on the timetable 2016 data. The direct costs of railway capacity allocation stated in the annual report of the Railway Infrastructure 
Administration (25) were established by the Railway Infrastructure Administration economic department to be about CZK 106,780,000.

\section{Creating a model for calculation}

The authors start from the consideration that the total amount collected for railway capacity allocation (revenue from railway capacity allocation) must be lower or equal to the direct costs of railway capacity allocation. The following relation thus applies:

$$
\sum_{c=1}^{c=10} v_{c} \leq \sum_{c=1}^{c=10} n_{c}
$$

where:

$\mathrm{V}_{\mathrm{c}}$ is the total revenue from railway capacity allocation $[\mathrm{CZK}]$,

$n_{c}$ are the total direct costs of rail capacity allocation $[\mathrm{CZK}]$.

The individual vc products are marked as follows: v1 is the price of capacity allocation for individual requests for RJ, v2 is the price of capacity allocation for individual requests for $\mathrm{PJ}, \mathrm{v} 3$ is the price of capacity allocation for individual requests for $\mathrm{ZJ}, \mathrm{v} 4$ is the price of capacity allocation for individual requests for N3, v5 is the price of capacity allocation for individual requests for P3, v6 is the price of capacity allocation for individual requests for $\mathrm{TB}, \mathrm{v} 7$ is the price of capacity allocation for individual requests for $\mathrm{ZK}, \mathrm{v} 8$ is the price of capacity allocation for individual requests for UI, v9 is the price of capacity allocation for individual requests for OM, and v10 is the price of capacity allocation for individual requests for JD. For these vc the following relations apply:

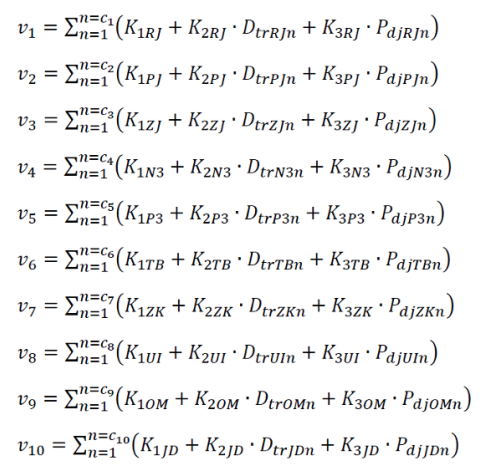

\section{Under the following conditions:}

$$
\begin{aligned}
& \left(K_{1 R J}+K_{2 R J} \cdot D_{t r R J m}+K_{3 R J} \cdot P_{d j R J m}\right)<\left(K_{1 N 3}+K_{2 N 3} \cdot D_{t r N 3 m}+K_{3 N 3} \cdot P_{d j N 3 m}\right) \\
& \left(K_{1 R J}+K_{2 R J} \cdot D_{t r R J m}+K_{3 R J} \cdot P_{d j R J m}\right)<\left(K_{1 P J}+K_{2 P J} \cdot D_{t r P J m}+K_{3 P J} \cdot P_{d j P J m}\right) \\
& \left(K_{1 R J}+K_{2 R J} \cdot D_{t r R J m}+K_{3 R J} \cdot P_{d j R J m}\right)<\left(K_{1 Z J}+K_{2 Z J} \cdot D_{t r Z J m}+K_{3 Z J} \cdot P_{d j Z J m}\right) \\
& \left(K_{1 N 3}+K_{2 N 3} \cdot D_{t r N 3 m}+K_{3 N 3} \cdot P_{d j N 3 m}\right)<\left(K_{1 P 3}+K_{2 P 3} \cdot D_{t r P 3 m}+K_{3 P 3} \cdot P_{d j P 3 m}\right) \\
& \left(K_{1 P J}+K_{2 P J} \cdot D_{t r P J}+K_{3 P J} \cdot P_{d j P J}\right)<\left(K_{1 N 3}+K_{2 N 3} \cdot D_{t r N 3}+K_{3 N 3} \cdot P_{d j N 3}\right) \\
& \left(K_{1 Z J}+K_{2 Z J} \cdot D_{t r Z J}+K_{3 Z J} \cdot P_{d j Z J}\right)<\left(K_{1 N 3}+K_{2 N 3} \cdot D_{t r N 3}+K_{3 N 3} \cdot P_{d j N 3}\right) \\
& K_{1 R J}+K_{2 R J} \cdot D_{t r R J}+K_{3 R J} \cdot\left(P_{d j}-1\right)_{R J}>K_{1 N 3}+K_{2 N 3} \cdot D_{t r N 3}+K_{3 N 3} \cdot\left(P_{d j}-1\right)_{N 3} \\
& K_{1 P J}+K_{2 P J} \cdot D_{t r P J}+K_{3 P J} \cdot\left(P_{d j}-1\right)_{P J}>K_{1 N 3}+K_{2 N 3} \cdot D_{t r N 3}+K_{3 N 3} \cdot\left(P_{d j}-1\right)_{N 3}
\end{aligned}
$$

Where:

$n$ is the number of kilometres, route-days of the nth request for railway capacity for product $\mathrm{c}_{\mathrm{n}}, \mathrm{n}=1,2,3$, $\ldots, \mathrm{cn}$,

$m$ is the number of limit kilometres, route-days for product $\mathrm{c}_{\mathrm{n}}, \mathrm{m}=1,2,3, \ldots, \mathrm{m}$,

$\mathrm{n}=\mathrm{cn}$ is the total number of requests for railway capacity for product $\mathrm{cn}$,

$v c_{1}, v c_{2}, v c_{3}, \ldots, v c 1$ is the revenue from railway capacity allocation for product $c 1, c 2, c 3, \ldots, c 10$ [CZK],

$c_{1}, c_{2}, c_{3}, \ldots, c 10$ is the total number of requests for railway capacity for product (RJ, PJ, ZJ, N3, P3,

TB, ZK, UI, OM and JD) [CZK],

$K 1$ is the price of processing and determining of the timetable and railway capacity allocation [CZK per route],

$K 2$ is the price of train route creation [CZK per $\mathrm{km}$ ],

$K 3$ is the price of train route allocation per day [CZK per day],

DtrRJ, DtrPJ, DtrZJ, DtrN3, DtrP3, DtrTB, DtrZK, $D t r U I, D t r O M, D t r J D$ is the route length for products (RJ, PJ, ZJ, N3, P3, TB, ZK, UI, OM, JD), the distance between point of origin and point of destination on railway network, where the Railway Infrastructure Administration functions as infrastructure manager, or capacity allocator $[\mathrm{km}]$,

$P d j R J, P d j P J, P d j Z J, P d j N 3, P d j P 3, P d j T B, P d j Z K$, $P d j U I, P d j O M, P d j J D$ is the number of route-days for $\mathrm{RJ}$ the respective route is allocated for [day],

The authors didn't include UI, OM a JD in the calculations as they do not factor in the price of railway capacity allocation as in accordance with applicable legal provisions, their price hasn't been set.

The authors simplified inequations (20), (21), (22) and (23) in the way described below, creating several invariables. Since coefficient K1 is the price of request processing, all requests processed in IS KANGO16 (products RJ, PJ and ZJ) have the same K1, and requests processed in IS KADR (products N3 and P3) have the same coefficient $\mathrm{K} 1$. The ratio between $\mathrm{K} 1$ value for requests processed in IS KANGO and requests processed in IS KADR is based on the current ratio and was established as 0.06 . For coefficient $\mathrm{K} 1$ for individual products, the author established the following relations: $K 1 R J=K 1 R J$

$K 1 P J=K 1 R J$ $K 1 Z J=K 1 R J$

The authors first modelled Option 0 reflecting the current situation and the current allocation charging scheme using the current coefficients $\mathrm{K} 1, \mathrm{~K} 2$ and $\mathrm{K} 3$. 
Table 7. Calculation for all requests based on coefficients (for total values)

\begin{tabular}{|l|l|l|l|l|l|l|l|l|}
\hline Product & $\mathbf{K 1}$ & $\begin{array}{l}\text { Number of } \\
\text { data } \\
\text { timetables }\end{array}$ & $\mathbf{K 2}$ & $\begin{array}{l}\text { Total } \\
\text { number of } \\
\text { kilometres }\end{array}$ & $\mathbf{K 3}$ & $\begin{array}{l}\text { Number of } \\
\text { route-days }\end{array}$ & $\begin{array}{l}\text { Price of } \\
\text { product } \\
\text { [CZK] }\end{array}$ & $\begin{array}{l}\boldsymbol{\emptyset} \text { price of 1 } \\
\text { request } \\
\text { [CZK] }\end{array}$ \\
\hline RJ & 1.700 & 13.686 & 8 & 731,593 & 10 & $2,899,051$ & $58,109,454$ & 4,246 \\
\hline PJ & 1.700 & 788 & 10 & 37,661 & 20 & 132,265 & $4,361,513$ & 5,534 \\
\hline ZJ & 1.700 & 485 & 10 & 33,727 & 20 & 32,170 & $1,805,166$ & 3,721 \\
\hline ZK & 960 & 285 & 0 & 11,492 & 70 & 367 & 299,290 & 1,051 \\
\hline TB & 480 & 196 & 0 & 9,742 & 70 & 196 & 107,800 & 550 \\
\hline N3 & 100 & 13.534 & 0 & $1,357,650$ & 70 & 26,400 & $3,201,400$ & 240 \\
\hline P3 & 100 & 159.968 & 0 & $11,491,204$ & 160 & 160,943 & $41,747,680$ & 260 \\
\hline Total price $[\mathbf{C Z K}]$
\end{tabular}

The total price in Table 7 is the current revenue from railway capacity allocation. The current direct costs of railway capacity allocation were established by the Railway Infrastructure Administration economic department to be about CZK 106,780,000. This amount shouldn't be exceeded. The difference between revenue and costs is approximately $2.67 \%$ (CZK 2,852,303). It is approximately this amount the revenue from railway capacity allocation needs to be reduced by while complying with the conditions of formulas (20), (21) (22), (23), (24) (25), (26) and (27). The break-even point of price between products is shown in Figure 1.

CZK

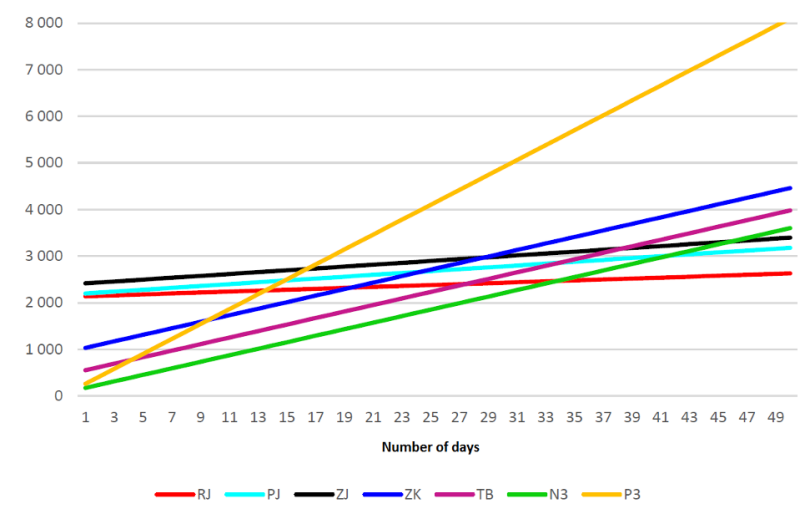

Fig. 1. The break-even point of price between products.

Table 8 Comparison of revenue from railway capacity allocation with total direct costs of railway capacity allocation

\begin{tabular}{|c|c|c|}
\hline $\begin{array}{c}\text { Revenue from } \\
\text { railway capacity } \\
\text { allocation }[\mathrm{CZK}]\end{array}$ & $\begin{array}{c}\text { Costs of } \\
\text { railway capacity } \\
\text { allocation }[\mathrm{CZK}]\end{array}$ & $\begin{array}{c}\text { Difference } \\
\text { between revenue } \\
\text { and costs [\%] }\end{array}$ \\
\hline $\mathbf{1 0 9 . 6 3 2 . 3 0 3}$ & $\mathbf{1 0 6 . 7 8 0 . 0 0 0}$ & $\mathbf{2 . 6 7}$ \\
\hline
\end{tabular}

Source: Authors

\section{Summary}

Current model for calculation of the price of railway capacity allocation using coefficients $\mathrm{K} 1, \mathrm{~K} 2$, and $\mathrm{K} 3$ in accordance with Table 8. In 2016, the revenue from railway capacity allocation was $2.67 \%$ higher than the total direct costs of railway capacity allocation.

In this paper, the authors defined the requirements on target groups of requests so that they can be attributed to individual products either in the mode of allocating railway capacity within the annual timetable, or in the ad hoc mode. This definition is vital for proper regulation of the demand of railway undertakings for individual products. The aim of the proposed model is for a part of the requests to move from the ad hoc mode to the annual timetable mode.

The work was supported from ERDF/ESF "Project PosiTrans - University of Pardubice cooperation and application sphere in application oriented research of localization, detection and simulation systems for transport processes" (No. CZ.02.1.01/0.0/0.0/17_049/0008394).

\section{References}

1. Directive no. 266/1994, Czech Republic, from 14th December 1994, on railways.

2. Derective 2012/34/EU of the European Parliament and of the council of 21 November 2012, establishing a single European railway area.

3. Directive no. 319/2016, Czech Republic, from 6th September 2016, on railways.

4. SŽDC, Network Statement (2015)

5. SŽDC, D1 - Transport and Signal Directive, (2012)

6. Directive. 526/1990, Czech Republic, from 27th November 1990, about prices, actual version 2015

7. Price Bulletin No. 12/2016 of 29th November 2016, Czech Republic

8. Ministry of Finance of Czech Republic, Decree No. 01/2017, of 25 November 2016, listing the regulated price list

9. AŽD Praha, Network Statement, available at: http:/www.azd.cz/admin/files/Dokumenty/pdf/Komp letni-zneni-Prohlaseni-o-draze-2017-CizkoviceObrnice-Kopidlno-Dolni-Bousov.pdf (2016)

10. J. Gašparík; B. Abramović, M. Halás Promet Traffic \& Transportation. 27, 4. 283-290. (2015)

11. Network Statement, Jindřichohradecké místní dráhy, a.s., available at: http://docplayer.cz/1333471Prohlaseni-o-draze-regionalni.html (2017)

12. Network Statement, Moravskoslezský kraj. available at: http://www.szdc.cz/soubory/prohlaseni-odraze/2017/01-04-17-prohlaseni-o-draze-20171zmena-mosnov.pdf (2017)

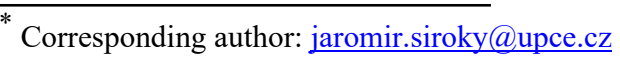


13. KŽC, Regional Network Statement, available at: http://www.kzc.cz/muzejni-zeleznice-senovka/ prohlaseni-o-draze (2014)

14. Železnice Desná, Network Statement, available at: http:/www.sart.cz/wpcontent/uploads/Prohlasení-odraze-aktualizace-2016.pdf (2015)

15.H. Saláková, Bachelor thesis: Sledování ekonomických faktorů pri přidělování kapacity železnični dopravní cesty. Univerzity of Pardubice (2015)

16. Decree No. 501/2005, Czech Republic, on the determination of the costs of the operator of the railway connected with the operation and ensuring of operability, modernization and development of the railway infrastructure, (2006)

17. Network Statement. DB NETZE. available at: http://fahrweg.dbnetze.com/fahrwegen/network_acce ss/network_statement/2017.html (2016)

18. Network Statement. PKP PLK. available at: http://en.plk_sa.pl/files/public/user_upload/pdf/Reg przydzielania tras/Regulamin_2016_2017/Network Statement_2016-2017_v11.pdf (2016)

19. Network Statement. ÖBB Infrastruktur AG. available at:

http://www.oebb.at/infrastruktur/en/Network Access //NetworkStatement/2017.jsp (2016)
20. Product Catalogue 2017 Train Path. ÖBB Infrastruktur AG. available at: http://www.oebb.at/infrastruktur//en/Network Acces s/Product_Train_Path.jsp (2016)

21. ŽSR, Conditions for using the railway network for GVD 2016/2017. available at: http://www.zsr.sk//Marketing/PodmPouzivaniaZelez nicnejSiete2017.pdf (2016)

22. J. Gašparík, V. Zitrický. Promet-Traffic and Transport. 27, 4, 283-290. (2015)

23. V. Zitrický, L. Černá, B. Abramović. Procedia Engineering. 192. 994-999. 2017.

24. SŽDC, Annual report 2016, available at: http://www.szdc.cz/soubory/vysledkyhospodareni.pdf (2017)

25. Train Path Pricing System (TPS). DB Netz. [available at: http://fahrweg.dbnetze.com/train_path_pricing_syste m_2017.pdf (2016)

26. S. Stoilova. International Multidisciplinary Scientific Conferences on Social Sciences and Arts. 627-634. (2016)

27. Gasparik, J.; Majercak, J.; Siroky, J.; Abramovic, B.; Mesko, P.; Nachtigall, P.; Zitricky, V. 2017. Railway Traffic Operation. Žilina: Žilinská univerzita, 292 p.

28. Široký, J.; Cempírek， V.; Gasparik， J. 2014. Transport Technology and Control. Brno: Tribun EU, $238 \mathrm{p}$. 